\title{
Research on the Performance Evaluation of Small and Micro Businesses Microfinance of Commercial Bank based on Balanced Scorecard and Principal Components Analysis
}

\author{
Qiguang Zhang ${ }^{1}$ \\ ${ }^{1}$ School of Management, \\ Harbin Institute of Technology, \\ Haerbin, China
}

\author{
Wei Guo ${ }^{2}$ \\ ${ }^{2}$ School of Management, \\ Huazhong University of Science and Technology, \\ Wuhan, China
}

\begin{abstract}
According to the principals of Balanced Scorecard (BSC), we designed the performance evaluation system from five dimensions and evaluated the performance of small and micro businesses microfinance of 8 branches of HARBIN BANK by using Principal Components Analysis (PCA). The effectiveness and practicability of our method were verified by the empirical results and suggestions were recommended to improve the performance of microfinance.
\end{abstract}

Keywords-performance evaluation; balanced scorecard; principal components analysis; microfinance

\section{INTRODUCTION}

In China, the banking industry has an intense competition because of the establishment of many small and medium sized banks. The large-scale commercial banks have advantages in capital, big clients and other aspects, so it is difficult to challenge them. What's more, small and medium-sized banks have no differences in customers, business features, so the competition between them are very intense. How to become the winner in the competition becomes the main point of banks' strategy development.

Microfinance becomes one of the most important businesses and the strategy center of many Chinese small and medium-sized joint-stock banks. Effective performance evaluation can help banks to evaluate the current situation and provide useful information for future development. Therefore, it is an important research subject for many small and medium-sized joint-stock banks.

\section{LITERATURE REVIEW}

Many performance evaluation systems can be used to evaluate banks' performance, such as "CAMEL" rating system, the standard \& poor's bank rating system, EVA and BSC. Evaluation method like Factor analysis, Data Envelopment Analysis (DEA) and PCA are widely used. Xiong Weiping, Zhu Shuhong [1] pointed that all indicator convert to positive indicators before PCA can get more scientific and effective results. Qin Wanshun, Ouyang Jun [2] evaluated Chinese banks' efficiency using DEA and found that Chinese banks' efficiency is poor and stateowned banks are the poorest. Tan Zhongming [3] used factor analysis to evaluate 12 banks’ performance of 1992. Serpil Canbas, Altan Cabuk, Suleyman Bilgin Kilic [4] evaluated more than 40 Turkey's banks by using PCA and built a risks warning system. Chen Zonghua [5] built a performance evaluation model based on profitability, security and liquidity and used PCA to analyzed Chinese banks and found that state-owned banks' performance are lower than average. Guo Linyan [6] used Factor analysis to evaluate performance of Chinese commercial banks of 2011. Thagunna, Poudel [7] used DEA to evaluate the performance of Nepal Bank from 2007 to 2011 and found that its performance has improved these years. Peng Wanlu, Huang Jun [8] used PCA to evaluate 20 banks' competiveness and found that Chinese banks are better than foreign banks in operating performance and comprehensive competitiveness and foreign banks are much better in risk management and business innovation.

We can conclude that BSC can build a comprehensive and effective performance evaluation system, which is used enterprise value maximization as the target and evaluates the performance from finance, customer, internal process and learning and growth dimension. What's more, it can be adjusted according to bank's own situation. PCA is widely used in performance evaluation, which dimension reduction technology to convert all indicators into several comprehensive indicators and make the evaluation more objective and comparable. Therefore, we use the principal of BSC to build the evaluation performance system of small and micro businesses microfinance of Chinese small and medium-sized banks and use PCA to analyze and rank the performance results.

\section{CONSTRUCTION OF PERFORMANCE EVALUATION MODEL}

BSC often evaluates the performance of companies or banks from 4 dimensions which are finance, customer, internal process and learning and growth. However, it does not mean that it only has four dimensions. According to the industry condition and strategy of the company, it is necessary to add one or more new dimensions. Small and micro businesses microfinance is one of the important source of profit of small and medium-sized banks and it is also the social responsibility of banks to support small and micro businesses. Many small and micro businesses are 
high-tech, clean energy or companies in emerging industry supported by government. It also reflects banks social responsibility by supporting them with financing. Therefore, we designed a BSC performance evaluation model with five dimensions which are finance, customer, internal process, learning and growth and social responsibility.

"Table I" is the performance evaluation model.

TABLE I. PERFoRMANCE EVALUATION MODEL.

\begin{tabular}{|c|c|c|}
\hline $\begin{array}{l}\text { First Class } \\
\text { Indicator }\end{array}$ & $\begin{array}{l}\text { Second Class } \\
\text { Indicator }\end{array}$ & Third Class Indicator \\
\hline \multirow[t]{19}{*}{ Finance } & \multirow[t]{4}{*}{ Security } & RAROC $x_{1}$ \\
\hline & & The impairment loss $\mathrm{x}_{2}$ \\
\hline & & Asset quality $\mathrm{x}_{3}$ \\
\hline & & Non-performing loan ratio $\mathrm{x}_{4}$ \\
\hline & \multirow[t]{6}{*}{ Development } & Profit growth rate $x_{5}$ \\
\hline & & $\mathrm{EVA}_{6}$ \\
\hline & & $\begin{array}{l}\text { Percentage of revenue in total } \\
\text { revenue } x_{7}\end{array}$ \\
\hline & & Importance of microfinance $\mathrm{x}_{8}$ \\
\hline & & Growth rate of loan $\mathrm{x}_{9}$ \\
\hline & & Loan concentration $\mathrm{x}_{10}$ \\
\hline & \multirow[t]{4}{*}{ Profitability } & $\begin{array}{c}\text { Return on total assets of microfin- } \\
\text { ance } x_{11}\end{array}$ \\
\hline & & Return on equity of microfinance $\mathrm{x}_{12}$ \\
\hline & & Net interest rate $\mathrm{x}_{13}$ \\
\hline & & Net profit rate $\mathrm{x}_{14}$ \\
\hline & \multirow[t]{5}{*}{ Efficiency } & Before tax profit per person $\mathrm{x}_{15}$ \\
\hline & & Cost to revenue $x_{16}$ \\
\hline & & Net profit to cost $x_{17}$ \\
\hline & & Amount of lending per person $\mathrm{x}_{18}$ \\
\hline & & $\begin{array}{l}\text { Amount of lending per Sub-branch } \\
\mathrm{X}_{19}\end{array}$ \\
\hline \multirow[t]{8}{*}{ Customer } & \multirow[t]{3}{*}{ Satisfaction } & Growth rate of customers $\mathrm{x}_{20}$ \\
\hline & & $\begin{array}{l}\text { Percentage of the regular customers } \\
\qquad \mathrm{X}_{21} \\
\end{array}$ \\
\hline & & Retention rate $\mathrm{x}_{22}$ \\
\hline & \multirow[t]{3}{*}{ Coverage } & Share of the stock market $\mathrm{x}_{23}$ \\
\hline & & Share of the new market $x_{24}$ \\
\hline & & Business success rate $x_{25}$ \\
\hline & \multirow[t]{2}{*}{ Improvement } & Customer income growth rate $\mathrm{x}_{26}$ \\
\hline & & Customer accession rate $x_{27}$ \\
\hline \multirow{6}{*}{$\begin{array}{l}\text { Internal } \\
\text { process }\end{array}$} & & Percentage of professionals $\mathrm{X}_{28}$ \\
\hline & & Growth rate of professionals $x_{29}$ \\
\hline & & Customers to staff $\mathrm{x}_{30}$ \\
\hline & & Approval time $\mathrm{x}_{31}$ \\
\hline & & $\begin{array}{l}\text { Efficiency of process improvement } \\
\mathrm{x}_{32} \\
\end{array}$ \\
\hline & & Corrective rate $\mathrm{x}_{33}$ \\
\hline \multirow{5}{*}{$\begin{array}{l}\text { Learning and } \\
\text { growth }\end{array}$} & & Training investment rate $\mathrm{x}_{34}$ \\
\hline & & Average training hour $\mathrm{x}_{35}$ \\
\hline & & Knowledge level of staff $x_{36}$ \\
\hline & & Staff turnover rate $x_{37}$ \\
\hline & & Staff induction rate $\mathrm{x}_{38}$ \\
\hline
\end{tabular}

\begin{tabular}{|c|c|}
\hline & Quantity of service innovation $\mathrm{x}_{39}$ \\
\hline & Products utilization rate $\mathrm{x}_{40}$ \\
\hline $\begin{array}{c}\text { Social } \\
\text { responsibility }\end{array}$ & $\begin{array}{l}\text { Percentage of customer supported by } \\
\text { government } x_{41}\end{array}$ \\
\hline & $\begin{array}{l}\text { Percentage of industries supported } \\
\text { by government } \mathrm{X}_{42}\end{array}$ \\
\hline & Tax contribution of customers $\mathrm{X}_{43}$ \\
\hline & Growth rate of tax contribution $\mathrm{X}_{44}$ \\
\hline & Percentage of innovative companies \\
\hline & Employment contribution $\mathrm{x}_{46}$ \\
\hline
\end{tabular}

IV. EMPIRICAL ANALYSIS OF PERFORMANCE

EVALUATION OF SMALL AND MICRO BUSINESSES MICROFINANCE

Our research object is HARBIN Bank. Microfinance is the most important business and the strategy center. Loan balance of microfinance takes $69.1 \%$ of total loan. Interest income from microfinance is $67.9 \%$ of total customer interest income. Microfinance becomes HARBIN Bank's core business and the number of small and micro businesses microfinance is over 33,000 . Our purpose is to establish effective performance evaluation model to evaluate the development of banks' microfinance by empirical analysis of HARBIN Bank and provide information for future development and improvement.

\section{A. Eigenvalue, percentage of variance, and cumulative} variance

After applying dimensionless method, we get standardized indicators and use the factor analysis function of SPSS17.0 to obtain eigenvalue, variance and cumulative variance. "Table II" is the total variance explained.

According to the result in "Table II," the percentage of cumulative variance reaches to $87.401 \%$ which is greater than $80 \%$, when there are 5 condition satisfied eigenvalues. It means that extracting these 5 components from 46 indicators can explain the performance of 8 branches efficiently and the target of dimension reduction is met.

\section{B. Analysis of component score coefficient matrix}

"Table III" is the component score coefficient matrix. We can get the formula of each component by multiplication of coefficient and corresponding indicator and add all together. This formula can be used to evaluate all samples.

TABLE II. TOTAL VARIANCE EXPLAINED.

\begin{tabular}{|c|c|c|c|c|c|c|}
\hline \multirow{2}{*}{$\begin{array}{c}\text { Compo- } \\
\text { nent }\end{array}$} & \multicolumn{3}{|c|}{ Initial Eigenvalues } & \multicolumn{3}{c|}{$\begin{array}{c}\text { Extraction Sums of Squared } \\
\text { Loadings }\end{array}$} \\
\cline { 2 - 7 } & Total & $\begin{array}{c}\text { \% of } \\
\text { Variance }\end{array}$ & $\begin{array}{c}\text { Cumula- } \\
\text { tive \% }\end{array}$ & Total & $\begin{array}{c}\text { of } \\
\text { Variance }\end{array}$ & $\begin{array}{c}\text { Cumula- } \\
\text { tive \% }\end{array}$ \\
\hline 1 & $\begin{array}{c}10.37 \\
5\end{array}$ & 22.554 & 22.554 & $\begin{array}{c}10.37 \\
5\end{array}$ & 22.554 & 22.554 \\
\hline 2 & 9.561 & 20.784 & 43.338 & 9.561 & 20.784 & 43.338 \\
\hline 3 & 7.842 & 17.047 & 60.385 & 7.842 & 17.047 & 60.385 \\
\hline 4 & 6.561 & 14.264 & 74.649 & 6.561 & 14.264 & 74.649 \\
\hline 5 & 5.866 & 12.753 & 87.401 & 5.866 & 12.753 & 87.401 \\
\hline 6 & 3.601 & 7.828 & 95.23 & 3.601 & 7.828 & 95.23 \\
\hline 7 & 2.194 & 4.77 & 100 & 2.194 & 4.77 & 100 \\
\hline
\end{tabular}


TABLE III. COMPONENT SCORE COEFFICIENT MATRIX.

\begin{tabular}{|c|c|c|c|c|c|}
\hline \multirow{3}{*}{ Zscore $\left(\mathrm{X}_{1}\right)$} & \multicolumn{5}{|c|}{ Component } \\
\hline & 1 & 2 & 3 & 4 & 5 \\
\hline & 0.053 & -0.057 & -0.061 & -0.019 & 0.063 \\
\hline Zscore $\left(\mathrm{X}_{2}\right)$ & -0.003 & 0.01 & 0 & 0.151 & 0.012 \\
\hline Zscore $\left(X_{3}\right)$ & 0.032 & -0.021 & -0.049 & 0.046 & -0.017 \\
\hline Zscore $\left(\mathrm{X}_{4}\right)$ & -0.004 & 0.003 & -0.054 & 0.134 & 0.03 \\
\hline Zscore $\left(X_{5}\right)$ & -0.069 & -0.003 & 0.033 & 0.03 & 0.1 \\
\hline Zscore $\left(\mathrm{X}_{6}\right)$ & 0.061 & 0.008 & 0.084 & 0.048 & 0.037 \\
\hline Zscore $\left(\mathrm{X}_{7}\right)$ & -0.078 & 0.04 & 0.013 & 0.025 & -0.042 \\
\hline Zscore $\left(\mathrm{X}_{8}\right)$ & 0.057 & 0.081 & -0.012 & 0.005 & 0.019 \\
\hline Zscore $\left(\mathrm{X}_{9}\right)$ & 0.013 & 0.09 & -0.026 & 0.03 & 0.035 \\
\hline Zscore $\left(\mathrm{X}_{10}\right)$ & 0.05 & -0.004 & 0.101 & 0.043 & 0.025 \\
\hline Zscore $\left(\mathrm{X}_{11}\right)$ & 0.072 & 0.024 & 0.002 & -0.052 & -0.01 \\
\hline Zscore $\left(\mathrm{X}_{12}\right)$ & 0.051 & -0.011 & 0.099 & 0.029 & 0.025 \\
\hline Zscore $\left(\mathrm{X}_{13}\right)$ & 0.083 & 0.028 & -0.033 & -0.033 & -0.042 \\
\hline Zscore $\left(\mathrm{X}_{14}\right)$ & 0.087 & -0.01 & 0.003 & 0.042 & 0.015 \\
\hline Zscore $\left(\mathrm{X}_{15}\right)$ & 0.067 & 0.056 & 0.028 & 0.041 & 0.028 \\
\hline Zscore $\left(\mathrm{X}_{16}\right)$ & -0.046 & 0.032 & -0.075 & -0.066 & 0.058 \\
\hline Zscore $\left(\mathrm{X}_{17}\right)$ & 0.011 & 0.049 & -0.057 & -0.101 & 0.008 \\
\hline Zscore $\left(\mathrm{X}_{18}\right)$ & 0.05 & 0.079 & -0.037 & 0.031 & 0.022 \\
\hline Zscore $\left(\mathrm{X}_{19}\right)$ & 0.032 & 0.069 & -0.033 & 0.032 & 0.003 \\
\hline Zscore $\left(\mathrm{X}_{20}\right)$ & -0.013 & 0.099 & -0.008 & -0.019 & 0.036 \\
\hline Zscore $\left(\mathrm{X}_{21}\right)$ & 0.002 & 0.062 & 0.04 & -0.068 & 0.097 \\
\hline Zscore $\left(\mathrm{X}_{22}\right)$ & 0.004 & 0.079 & -0.04 & -0.061 & 0.052 \\
\hline Zscore $\left(\mathrm{X}_{23}\right)$ & 0.052 & -0.023 & 0.088 & -0.003 & 0.058 \\
\hline Zscore $\left(X_{24}\right)$ & 0.017 & -0.046 & -0.002 & -0.059 & -0.044 \\
\hline Zscore $\left(\mathrm{X}_{25}\right)$ & -0.04 & 0.061 & 0.036 & 0.085 & -0.048 \\
\hline Zscore $\left(\mathrm{X}_{26}\right)$ & 0.001 & 0.003 & -0.06 & 0.075 & -0.016 \\
\hline Zscore $\left(\mathrm{X}_{27}\right)$ & 0.037 & -0.033 & -0.09 & 0.029 & 0.044 \\
\hline Zscore $\left(\mathrm{X}_{28}\right)$ & -0.077 & 0.03 & 0.022 & -0.045 & 0.006 \\
\hline Zscore $\left(\mathrm{X}_{29}\right)$ & -0.04 & 0.052 & -0.089 & 0.007 & -0.04 \\
\hline Zscore $\left(\mathrm{X}_{30}\right)$ & 0.001 & 0.009 & 0.09 & 0.073 & 0.068 \\
\hline Zscore $\left(\mathrm{X}_{31}\right)$ & -0.064 & 0.028 & 0.007 & 0.042 & -0.099 \\
\hline Zscore $\left(\mathrm{X}_{32}\right)$ & 0.004 & -0.011 & 0.011 & 0.009 & -0.165 \\
\hline Zscore $\left(\mathrm{X}_{33}\right)$ & -0.036 & 0.061 & 0.071 & 0.02 & -0.065 \\
\hline Zscore $\left(\mathrm{X}_{34}\right)$ & 0.018 & -0.065 & -0.059 & -0.029 & 0.094 \\
\hline Zscore $\left(\mathrm{X}_{35}\right)$ & -0.016 & -0.061 & -0.012 & 0.001 & -0.127 \\
\hline Zscore $\left(\mathrm{X}_{36}\right)$ & -0.014 & -0.067 & 0.055 & -0.033 & -0.029 \\
\hline Zscore $\left(\mathrm{X}_{37}\right)$ & 0.055 & 0.024 & -0.015 & -0.045 & -0.104 \\
\hline Zscore $\left(\mathrm{X}_{38}\right)$ & 0.013 & -0.033 & -0.015 & -0.086 & -0.008 \\
\hline Zscore $\left(\mathrm{X}_{39}\right)$ & -0.028 & -0.007 & -0.101 & 0.077 & 0 \\
\hline Zscore $\left(\mathrm{X}_{40}\right)$ & 0.015 & 0.004 & 0.076 & -0.114 & -0.031 \\
\hline Zscore $\left(\mathrm{X}_{41}\right)$ & 0.011 & 0.047 & 0.061 & 0.004 & -0.111 \\
\hline Zscore $\left(\mathrm{X}_{42}\right)$ & -0.051 & 0.069 & 0.034 & -0.058 & -0.013 \\
\hline Zscore $\left(X_{43}\right)$ & -0.066 & 0.005 & 0.037 & 0.036 & 0.097 \\
\hline
\end{tabular}

\begin{tabular}{|l|c|c|c|c|l|}
\hline Zscore $\left(\mathrm{X}_{44}\right)$ & 0.068 & 0.052 & -0.002 & 0.011 & -0.041 \\
\hline Zscore $\left(\mathrm{X}_{45}\right)$ & 0.025 & 0.074 & -0.013 & -0.049 & -0.013 \\
\hline Zscore $\left(\mathrm{X}_{46}\right)$ & -0.057 & 0 & 0.033 & -0.066 & 0.102 \\
\hline
\end{tabular}

According to the component score coefficient matrix, we can get the expressions of the 5 components.

$f_{1}=0.053 \times Z \operatorname{Zscore}\left(X_{1}\right)+\ldots+(-0.057) \times Z \operatorname{Zscore}\left(X_{46}\right)(1)$

$f_{2}=(-0.057) \times Z s c o r\left(E X_{1}\right)+\ldots+0.000 \times Z s c o r\left(X_{46}\right)$

$f_{3}=(-0.061) \times Z \operatorname{Zcor}\left(X_{1}\right)+\ldots+0.033 \times Z \operatorname{Zsor}\left(X_{46}\right)$

$f_{4}=\left(-0.019 \times Z s c o r\left(\left(X_{1}\right)+\ldots+\left(-0.060 \times Z \operatorname{Zscor}\left(e X_{46}\right)\right.\right.\right.$

$f_{5}=0.063 \times Z \operatorname{scor}\left(X_{1}\right)+\ldots+0.102 \times Z \operatorname{scor}\left(X_{46}\right)$

TABLE IV. THE FACTOR SCORE OF FIVE COMPONENTS.

\begin{tabular}{|c|c|c|c|c|c|}
\hline Branch & C1 & C 2 & C 3 & C4 & C5 \\
\hline Mudanjiang & $\begin{array}{c}-0.3067 \\
8\end{array}$ & 0.3474 & 0.59848 & $\begin{array}{c}-2.2888 \\
9\end{array}$ & $\begin{array}{c}-0.4479 \\
2\end{array}$ \\
\hline $\begin{array}{c}\text { Shuangya- } \\
\text { shan }\end{array}$ & $\begin{array}{c}-0.3330 \\
6\end{array}$ & $\begin{array}{c}-1.1077 \\
6\end{array}$ & 0.0429 & 0.5329 & $\begin{array}{c}-1.9568 \\
2\end{array}$ \\
\hline Suihua & -0.2436 & 0.80285 & -0.7221 & 0.44902 & -0.0951 \\
& 4 & & 3 & & 7 \\
\hline Dalian & 0.73753 & 1.62392 & $\begin{array}{c}-0.5897 \\
9\end{array}$ & 0.17261 & 0.01111 \\
\hline Harbin & 1.2342 & -0.1352 & 1.95864 & 0.65401 & 0.44266 \\
\hline Hegang & -1.9093 & -0.2278 & 0.43373 & 0.3742 & 1.27786 \\
\hline Jixi & 0.99608 & -1.5034 & -1.2241 & -0.5266 & 1.03107 \\
& & 2 & 6 & 5 & \\
\hline Shenyang & -0.1749 & 0.20009 & -0.4976 & 0.63282 & -0.2628 \\
& 9 & & 7 & & \\
\hline
\end{tabular}

TABLE V. The Ranking of Performance Evaluation.

\begin{tabular}{|c|c|c|c|c|c|c|}
\hline Branch & C1 & Ranking & C2 & Ranking & C3 & Ranking \\
\hline Mudanjiang & -0.3067 & 6 & 0.3474 & 3 & 0.59848 & 2 \\
\hline Shuangyashan & -0.3330 & 7 & -1.1077 & 7 & 0.0429 & 4 \\
\hline Suihua & -0.2436 & 5 & 0.8028 & 2 & -0.7221 & 7 \\
\hline Dalian & 0.7375 & 3 & 1.6239 & 1 & -0.5897 & 6 \\
\hline Harbin & 1.2342 & 1 & -0.1352 & 5 & 1.9586 & 1 \\
\hline Hegang & -1.9093 & 8 & -0.2278 & 6 & 0.4337 & 3 \\
\hline Jixi & 0.9960 & 2 & -1.5034 & 8 & -1.2241 & 8 \\
\hline Shenyang & -0.1749 & 4 & 0.2000 & 4 & -0.4976 & 5 \\
\hline Branch & C4 & Ranking & C5 & Ranking & Total score & Ranking \\
\hline Mudanjiang & -2.2888 & 8 & -0.4479 & 7 & -0.2785 & 7 \\
\hline Shuangyashan & 0.5329 & 3 & -1.9568 & 8 & -0.4715 & 8 \\
\hline Suihua & 0.4490 & 4 & -0.0951 & 5 & 0.0407 & 3 \\
\hline Dalian & 0.1726 & 6 & 0.0111 & 4 & 0.4293 & 2 \\
\hline Harbin & 0.6540 & 1 & 0.4426 & 3 & 0.7338 & 1 \\
\hline Hegang & 0.3742 & 5 & 1.2778 & 1 & -0.1877 & 5 \\
\hline Jixi & -0.5266 & 7 & 1.0310 & 2 & -0.2401 & 6 \\
\hline Shenyang & 0.6328 & 2 & -0.2628 & 6 & -0.0259 & 4 \\
\hline
\end{tabular}




\section{The factor score of five components}

To analyze the performance of 8 branches, the standardized indicators should be substituted into the expression (5) to (9) and the factor score of each component can be calculated. "Table IV" is the score of five components of each branch.

To eliminate the influence of subjective factors, we choose objective weight method to calculate the comprehensive score. From "Table II," we can get the weight of Component 1 is $22.55 \%$, Component 2 is $20.75 \%$, Component 3 is $17.05 \%$, Component 4 is $14.26 \%$, Component 5 is $12.38 \%$.

We assume that $\mathrm{f} 1, \mathrm{f} 2, \mathrm{f} 3, \mathrm{f} 4, \mathrm{f} 5$ is the score of each component and $\mathrm{F}$ is the expression of the comprehensive score. The expression is:

$$
F=2255 \% \times f_{1}+2075 \% \times f_{2}+17.05 \% \times f_{3}+1426 \% \times f_{4}+123 \% \% \times f_{5}
$$

The comprehensive score can be calculated by expression (10) and the ranking of the performance evaluation can be also obtained. "Table V" is the ranking of performance evaluation.

From the "Table V," Harbin branch has the greatest comprehensive score, so its performance evaluation is best. The second to fifth is Dalian, Suihua, Shenyang, Hegang, Jixi, and Mudanjiang. Shuangyashan is the last.

\section{CONCLUSIONS}

This article built the performance evaluation model of small and micro businesses microfinance based on BSC for small and medium-sized commercial banks and used PCA to evaluate the performance of small and micro businesses microfinance of 8 branches of HARBIN Bank in 2013. Finally, analyzed the empirical results from 5 components.

We made suggestions, such as developing new customers, increase the loan to promising and innovative companies, improving the efficiency of business process and increasing the investment in staff training, to the branches who performed worst in each component based on the analysis results.
Our search method and conclusions can provide useful suggestions to improve the performance of small and micro businesses microfinance for Chinese commercial banks.

\section{ACKNOWLEDGMENTS}

The work described in this paper is supported by a grant from Soft science fund of Department of science and technology, Hubei province (2013BDF009) and Huazhong University of Science and Technology Fundamental Research Funds for the Central Universities ("A research of performance evaluation of microfinance of small and medium sized commercial banks in the perspective of inclusive financial system”).

\section{REFERENCES}

[1] Xiong Weiping, Zhu Shuhong, Comprehensive evaluation and classification of commercial bank. Journal of Central South University, 4, pp. 328-332, 2001.

[2] Qin Wanshun, Ouyang Jun, The structure, efficiency and performance of Chinese commercial banking sector. Economic Science, 4, pp. 34-45, 2001.

[3] Tan Zhongming, An analysis on the efficiency of Chinese commercial banks. China Soft Science, 3, pp. 35-37, 2002.

[4] Serpil Canbas, Altan Cabuk, Suleyman Bilgin Kilic, Prediction of commercial bank failure via multivariate statistical analysis of financial structures: The Turkish case. European Journal of Operational Research, 2, pp. 528-546, 2005.

[5] Chen Zonghua, Research on the performance evaluation of Chinese listed commercial banks based on principal component analysis. Assets and Finances in Administration and Institution, 2, pp. 1-3, 2011.

[6] Guo Linyan, Performance appraisal on commercial banks based on factor analysis. Shanxi Science and Technology, 5, pp. 7-9, 2012.

[7] Thagunna Karan Singh, Poudel Shashank, Measuring bank performance of Nepali banks: A data envelopment analysis (DEA) perspective. International Journal of Economics and Financial Issues, 1, pp. 54-65, 2013.

[8] Peng Wanlu, Huang Jun, A comparative study on competitiveness between domestic and foreign banks based on principal component analysis. Accounting and Finance, 2, pp. 13-19, 2014. 